\title{
Preparation and Characterization of Edible Films Made from Modified Sweet Potato Starch through Heat Moisture Treatment
}

\author{
Novita Indrianti ${ }^{1,2, *}$, Yudi Pranoto1, and Akmadi Abbas ${ }^{3}$ \\ ${ }^{1}$ Department of Food and Agricultural Products Technology, Faculty of Agricultural Technology, Universitas Gadjah Mada, \\ J. Flora No. 1, Bulaksumur, Yogyakarta 55281, Indonesia \\ ${ }^{2}$ Development Centre of Appropriate Technology, Indonesian Institute of Sciences, \\ JI. KS Tubun No. 5 Subang 41213, West Java, Indonesia \\ ${ }^{3}$ Research Center for Biomaterials, Indonesian Institute of Sciences, Cibinong Science Center, \\ J. Raya Bogor Km.46, Cibinong, Bogor 16911, Indonesia
}

Received July 18, 2017; Accepted February 27, 2018

\begin{abstract}
The edible films were prepared from native sweet potato starch (SPS) or modified sweet potato starch through heat-moisture treatment (HMT). The treatments which were carried out in this research were the different durations of HMT (1, 2, and $3 \mathrm{~h}$ ) and the SPS concentrations (1, 1.25 and 1.5\%). The edible films were characterized by moisture content, thickness, tensile strength, elongation, water vapor permeability (WVP), solubility, morphology, thermal, and $x$-ray diffraction. The result showed that the thickness, the tensile strength, and the elongation of the modified SPS edible films were higher while the WVP and the solubility were lower than those of the native SPS edible films. The longer durations of HMT had no effects on the characteristics of the edible films. The increase of SPS concentrations enhanced the moisture content, the thickness, the WVP and the elongation but decreased the solubility and the tensile strength of edible films. The films surfaces of modified SPS edible films appeared to be denser and compact than those of native SPS edible films. The crystallinity and the thermal properties of the modified SPS edible films showed the higher increase than those of the native SPS edible films.
\end{abstract}

Keywords: sweet potato starch; heat-moisture treatment; edible film

\section{ABSTRAK}

Edible film dibuat dari pati ubi jalar alami atau pati ubi jalar termodifikasi Heat-Moisture Treatment (HMT). Perlakuan yang digunakan dalam penelitian ini yaitu perbedaan lama waktu HMT (1, 2, dan 3 jam) dan konsentrasi pati ubi jalar (1, 1,25, dan 1,5\%). Edible film dikarakterisasi kadar air, ketebalan, kuat tarik, elongasi, permeabilitas uap air, kelarutan, sifat morfologi, sifat termal, dan difraksi sinar X. Hasil menunjukkan bahwa ketebalan, kuat tarik, dan elongasi edible film dari pati ubi jalar termodifikasi HMT lebih tinggi sedangkan permeabilitas uap air dan kelarutan lebih rendah dibandingkan edible film dari pati ubi jalar alami. Semakin lama waktu HMT tidak berpengaruh terhadap karakterstik edible film. Kenaikan konsentrasi pati ubi jalar meningkatkan kadar air, ketebalan, permeabilitas uap air, dan elongasi tetapi menurunkan kelarutan dan kuat tarik edible film. Permukaan film dari edible film pati ubi jalar termodifikasi HMT lebih padat dan kompak dibandingkan dengan edible film pati ubi jalar alami. Kristalinitas dan sifat termal edible film pati ubi jalar modifikasi HMT menunjukkan peningkatan yang lebih tinggi dibandingkan edible film dari pati ubi jalar alami.

Kata Kunci: pati ubi jalar; heat-moisture treatment; edible film

\section{INTRODUCTION}

An edible film is a thin layer which can be consumed, coated the food or placed as a barrier between the food and the surrounding environment. Biopolymers such as polysaccharides, proteins, and lipids can be used for the formation of edible films. Meanwhile, starch has been considered as the most promising candidate for manufacturing biodegradable films because of its affordability, availability, renewability, and biodegradability. In addition, the starch films are known to be an effective barrier to gas transference like $\mathrm{O}_{2}$ and $\mathrm{CO}_{2}$ [1]. Sweet potato starch (SPS) is one of natural and abundant polysaccharide which is used in the production of edible films. In fact, the study on the chemical composition of sweet potato explains that SPS has high amylose content $23-30 \%$ [2]. In general, amylose is used in forming strong gel

* Corresponding author. Tel : +62-81328712782

DOI: $10.22146 /$ ijc.26740 
and film. Hence, the high amylose content will form a cohesive film matrix [3].

Sweet potato starch, in its native form, has limited applications in the industry because they are unstable concerning temperature changes and shear forces. Native starches show a strong tendency for decomposition and syneresis [4]. Based on the previous studies, edible films from native starches including sago starch, tapioca starch, and sugar palm starch have exposed several shortcomings such as brittleness, high sensitivity to moisture and poor mechanical properties [5-7]. Therefore, one of the methods for improving the quality of the edible films from starch is by using modified starches.

Chemical or physical modifications are used for improving the starch films properties. Chemically modified sweet potato starch through octenylsuccination shows better flexibility and barrier properties of edible films than that of native SPS edible films [8]. Nevertheless, the physical modification is more acceptable in food products since it is an environmentally friendly and low-cost method. Heat moisture treatment (HMT) is a physical modification which is carried out in a limited range of moisture content $(10-30 \%, w / w)$ and heated at above gelatinization temperature $\left(90-120^{\circ} \mathrm{C}\right)$ for a period ranging from $15 \mathrm{~min}$ to $16 \mathrm{~h}$ [4]. HMT increases the gelatinization temperatures and the thermal stability as well as reducing the granular swelling and the solubility of starches [9-12].

Previous studies have shown that the modified starch by HMT can increase the tensile strength and the elongation as well as reducing the WVP and the solubility of the edible films that are obtained from potato starch, Indian water chestnut starch and rice starch [1315]. HMT causes a higher crystalline structure to prevent granular swelling and increases the cohesion force in starch granules increasing the tensile strength and the decrease of the solubility of edible films [13]. In addition, HMT causes the displacement of double helices between starch crystals and arranges the formation of a better packaged crystalline array than those of native starch. The increase of crystallinity of the edible films enhances the compactness of the structure of the film [16]. Therefore, the main objective of this research was to investigate the characteristics of the edible films made from modified sweet potato starch through HMT with the different durations of HMT and starch concentrations.

\section{EXPERIMENTAL SECTION}

\section{Materials}

The materials used in this research were sweet potato starch (UKM Kusuka Ubiku, Yogyakarta), carrageenan (Setiaguna, Bogor) and glycerol (BRATACO, Bandung).

\section{Instrumentation}

The instruments used were a hot plate magnetic stirrer, a cabinet dryer, a desiccator, a plat acrylic, a micrometer (Mitutoyo), an electric oven (Memmert Instrument), Universal Testing Machine, a Scanning Electron Microscope (SEM Hitachi SU3500), a Differential Scanning Calorimeter (DSC-60 plus Shimadzu Japan), and a X-ray diffractometer (DSC Shimadzu Tokyo, Japan).

\section{Procedure}

\section{Modification of sweet potato starch through HMT}

The HMT was carried out in accordance with the Pranoto et al. (2014) method with slight modifications [10]. The modification of SPS through HMT was performed on the samples by adjusting moisture level to $25 \%$ and equilibrating it at $4{ }^{\circ} \mathrm{C}$ overnight. $100 \mathrm{~g}$ samples were placed in a covered baking pan and heated in an oven at $110^{\circ} \mathrm{C}$ for various time of 1,2 and $3 \mathrm{~h}$. After that, the samples were immediately cooled down to avoid further gelatinization and dried in a drying oven at $50{ }^{\circ} \mathrm{C}$ for $4 \mathrm{~h}$. The modified SPS through HMT was cooled down at ambient temperature and packed until further analysis.

\section{Preparation of edible films made from modified SPS through HMT}

The edible films of modified SPS through HMT were prepared according to the method [17] with slight modifications. The treatments which were carried out in this research were types of SPS (native, HMT $1 \mathrm{~h}, \mathrm{HMT}$ $2 \mathrm{~h}$, and HMT $3 \mathrm{~h}$ starches) and SPS concentrations (1, 1.25 and $1.5 \% \mathrm{w} / \mathrm{v})$. SPS aqueous suspensions (150 $\mathrm{mL})$ were heated with continuous mixing at $90-95^{\circ} \mathrm{C}$. $15 \mathrm{~mL}$ carrageenan aqueous suspensions ( $1 \% \mathrm{w} / \mathrm{v})$ were added and heated to a clear solution. SPS and carrageenan suspensions were mixed and heated at $90-95^{\circ} \mathrm{C} .15 \mathrm{~mL}$ glycerol $(1 \% \mathrm{w} / \mathrm{v})$ was added, and it stirred for $15 \mathrm{~min}$. The suspensions were filtered with filter cloth and degassed under vacuum $\left(60{ }^{\circ} \mathrm{C} 300\right.$ millibar for $1 \mathrm{~min}$ ). Subsequently, the suspensions (90 $\mathrm{mL}$ ) were poured into a plat acrylic $20 \mathrm{~cm} \times 20 \mathrm{~cm}$ and dried at $50{ }^{\circ} \mathrm{C}$ for $24 \mathrm{~h}$ in a cabinet dryer. The dried films were conditioned at room temperature and peeled off from the plat acrylic. The edible films were saved in a desiccator for 2-3 days before testing.

Moisture content. The moisture content (MC) of films was determined according to the method [17] with slight modifications. Films $( \pm 2 \mathrm{~g})$ were placed into predried weighing bottles and dried at $105^{\circ} \mathrm{C}$ in an electric 
oven (Memmert Instrument). The dried films were conditioned in a desiccator for 10-15 $\mathrm{min}$ and weighed using analytical balance. This step was repeated until reaching a constant weight. The $\mathrm{MC}$ of the edible films was calculated using Eq. 1.

$\mathrm{MC}(\%)=\frac{\mathrm{mi}-\mathrm{mf}}{\mathrm{mf}}$

where $\mathrm{mi}$ is the initial sample weight, and $\mathrm{mf}$ is the final sample weight.

Film thickness. The thickness of films was measured using a micrometer to the nearest $0.001 \mathrm{~mm}$. Measurements were taken randomly from 6 different points for individual film samples, and the average value was calculated. The results of the thickness measurement were used for assessing the water vapor permeability of edible films. All film samples were preconditioned in a constant temperature humidity chamber set at $50 \% \mathrm{RH}$ for at least $48 \mathrm{~h}$ before the further test [17].

\section{Tensile strength and elongation}

The mechanical properties of the edible films including the tensile strength (TS) and elongation at break (EB) were determined according to the standard ASTM method D 882-88 using Universal Testing Machine. The tensile strength and the percentage of elongation at break were calculated with Eq. 2 and 3.

$\mathrm{TS}=\frac{\mathrm{Fmax}}{\mathrm{A}}$

$E B(\%)=\frac{d r}{d o} \times 100$

where TS is the tensile strength (MPa); Fmax is the maximum force $(\mathrm{N})$; $A$ is the area of film cross-section $\left(\mathrm{mm}^{2}\right)$; $\mathrm{dr}$ is the distance of rupture $(\mathrm{mm})$ and do is the distance onset of separation $(\mathrm{mm})$ [18].

\section{Water vapor permeability (WVP)}

The WVP of the edible films was determined by ASTM E-96-95 standard method with slight modifications [18]. Initially, the films were cut in a square shape (diameter $5 \mathrm{~cm}$ ). The films were covered on a pre-filled weighing bottle that was filled with $10 \mathrm{~g}$ of dried silica gel. All bottles were placed in a desiccator filled with saturated magnesium nitrate solution $(50 \% \mathrm{RH})$ at room temperature. The WVTR (water vapor transmission rate in $\mathrm{g} / \mathrm{m}^{2}$ day) was calculated by the linear regression from the linear portion of the weight change versus time curve. Then the WVP of the films were calculated with Eq. 4.

$$
W V P=\frac{W V T R \times L}{\Delta P}
$$

where $L$ is the film thickness $(\mathrm{mm})$ and $\Delta P$ is the partial water vapor pressure difference $(\mathrm{Pa})$ across the two sides of the films.

\section{Solubility}

The solubility of edible films was estimated according to the previous method with slight modifications [19]. Films $( \pm 0.03 \mathrm{~g})$ were immersed in $50 \mathrm{~mL}$ of deionized water at room temperature for $24 \mathrm{~h}$. Undissolved portions were filtered out and dried in an oven at $105^{\circ} \mathrm{C}$ until a constant weight was reached. The solubility was calculated by Eq. 5 .

Solubility $=\frac{\mathrm{Wb}-\mathrm{Wa}}{\mathrm{Wa}} \times 100 \%$

where $\mathrm{Wb}$ is the initial mass of the sample before immersion, and $\mathrm{Wa}$ is the weight of the dried sample after immersion.

\section{Morphology analysis}

Morphology of films was analyzed using scanning electron microscope (SEM Hitachi SU3500). The films were prepared by placing them on an SEM holder and coating them with gold in a vacuum condition. The sample images were taken at $1000 \times$ magnification.

\section{Thermal analysis}

Thermal properties of edible films were analyzed by using a Differential Scanning Calorimeter (DSC-60 plus Shimadzu Japan). Approximately $3 \mathrm{mg}$ of the sample was sealed in an aluminum pan and heated from 25 to $400{ }^{\circ} \mathrm{C}$ at a heating rate of $10^{\circ} \mathrm{C} / \mathrm{min}$ [19].

\section{$X$-ray diffraction}

The X-ray diffraction and the crystallinity of samples were measured by using an X-ray diffractometer as previously described [19]. Samples $(3.5 \mathrm{~cm} \times 3 \mathrm{~cm})$ were fixed in a circular clamp of the instrument and scanned from 5 to $40^{\circ}$ at the speed of $2 \% \mathrm{~min}$. The current and voltages were $30 \mathrm{~mA}$ and $40 \mathrm{kV}$, respectively.

\section{RESULT AND DISCUSSION}

\section{Moisture Content}

Edible starch films are used for food protection to increase the shelf-life of the foodstuffs [20]. The moisture content of edible films was shown in Fig. 1. The moisture content of SPS edible films ranged from $12.79-14.71 \%$. The moisture content of modified SPS edible films had no significant difference from that of native SPS films $(P>0.05)$. The modified SPS through HMT did not affect the moisture content of the films.

The addition of $1.5 \%$ starch increased the moisture content of edible films $(P<0.05)$. The presence of water in the films depends on the starch concentration due to its hydrophilic properties which can retain water in the film matrix. Starch has the ability to absorb water because it has a hydroxyl group (Fig. 2). 


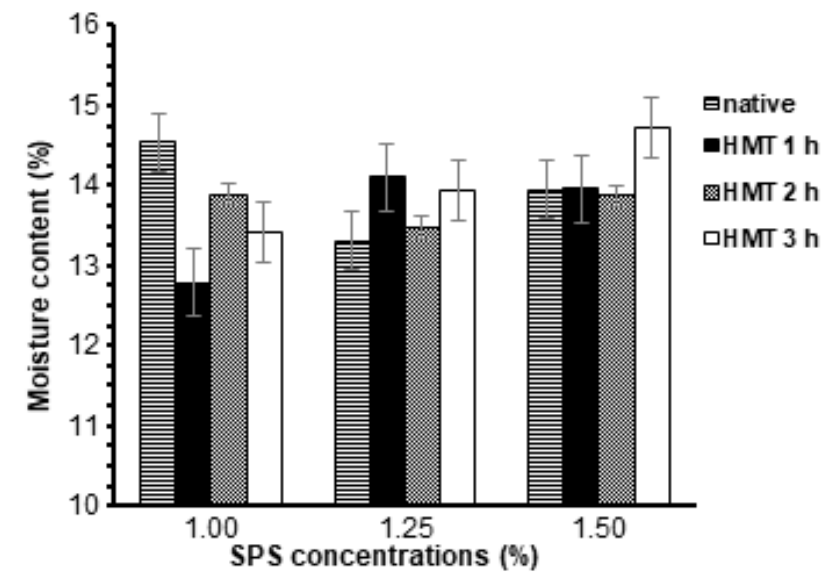

Fig 1. The moisture content of SPS edible films with different durations of HMT and starch concentrations

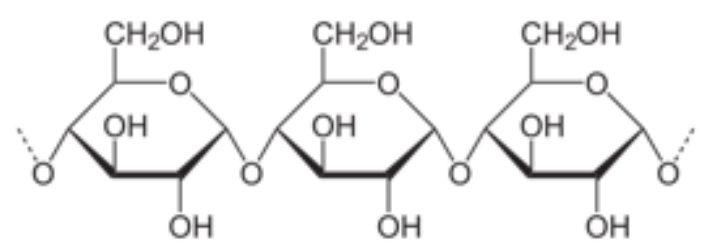

Fig 2. Structure of starch

The high starch concentration increased the water molecules adsorption. It is mainly because of the tendency of starch to form hydrogen bonds with oxygen and hydrogen of water molecules [3].

\section{Film Thickness}

The thickness of edible films was shown in Fig. 3. The thickness of films ranged from $0.054-0.068 \mathrm{~mm}$. It can be observed that the modified SPS edible films were significantly thicker than native SPS edible films $(P<$ 0.05). HMT increased the hydrogen bond so that the film matrix was thicker [13]. The longer durations of HMT had no significant effects on the film thickness.

The film's thickness significantly increased as the starch concentration increased $(P<0.05)$. The high starch concentration increased the total solids in the solution [17]. An increase of the total solids also increased the thickness of the film. Similar results were reported in the previous study where starch concentration had a profound effect on the thickness of potato starch films [13].

\section{Tensile Strength and Elongation}

Tensile strength and elongation are the parameters to describe the mechanical properties of the edible films which are related to their chemical structure. Experimental stress-strain curves were used for calculating the films tensile strength and elongation. These

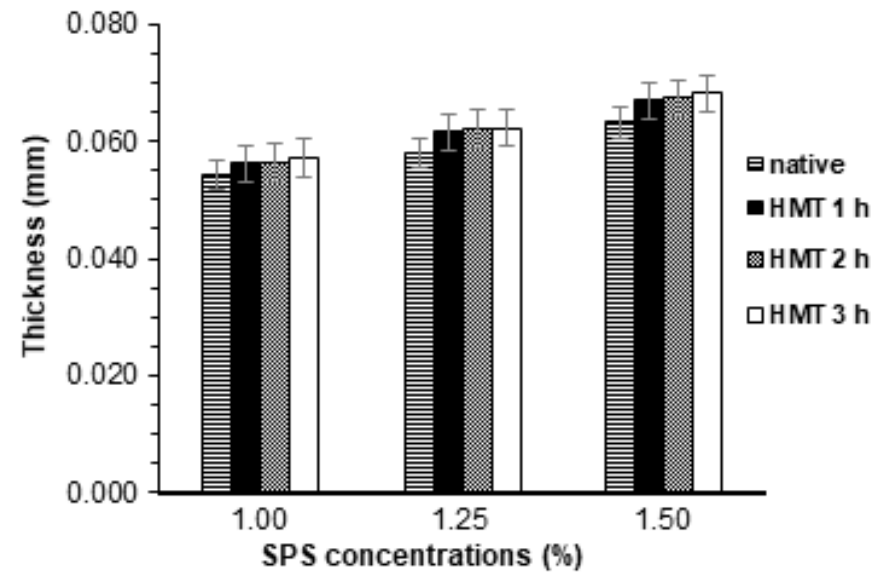

Fig 3. The thickness of SPS edible films with different durations of HMT and starch concentrations

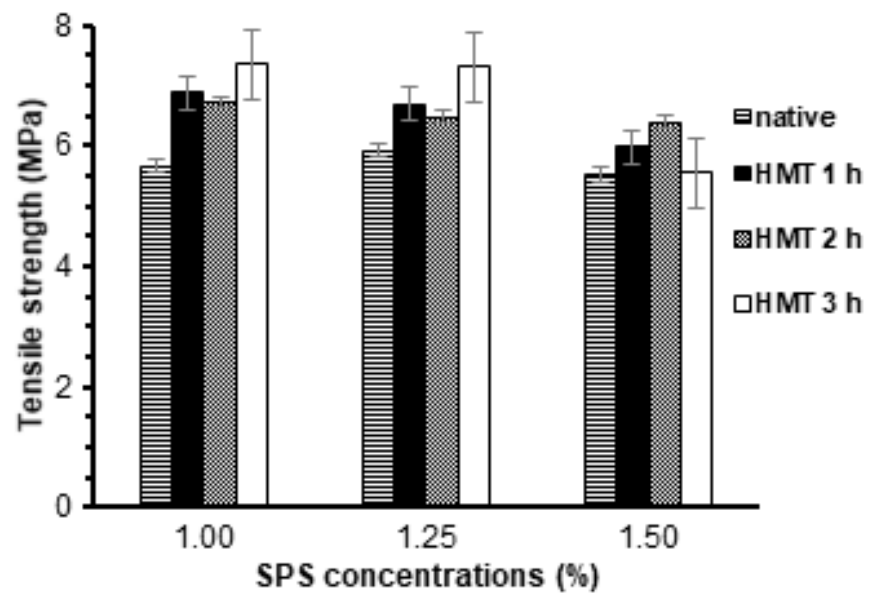

Fig 4. The tensile strength of SPS edible films with different durations of HMT and starch concentrations

properties are dependent on the polymeric chain packing, the chain interactions and the film thickness [8].

Tensile strength is defined as the maximum force which is used during a stress-strain experiment or the force obtained at the break of the sample point [21]. The result of the tensile strength of edible films is shown in Fig. 4.

The tensile strength of SPS edible films ranged from 5.52 and $7.31 \mathrm{MPa}$. Fig. 4 shows that the tensile strength of modified SPS edible films was significantly higher than that of native SPS films $(P<0.05)$. The longer durations of HMT had no significant effect on the tensile strength. HMT caused a stronger crystalline structure to increase the cohesion force in starch granules [22]. It enhanced the tensile strength of SPS edible films. In addition, HMT caused the displacement of double helices between starch crystals and arranged the formation of a better packaged crystalline array than those of native starch. As it is said, the increase of 
crystallinity of the films enhances the compactness of the structure of the film [16].

In this study, the addition of $1.5 \%$ starch decreased the tensile strength of SPS edible films $(P<0.05)$. The high starch concentration caused the residual granules to aggregate and disrupt the network of matrix film, resulting in a loss of the cohesive force in the film matrix [19]. Similar results also reported in a potato starch film [13]. In addition, the increase of SPS concentrations caused the weaker interaction of starch-carrageenan and less compact crystalline structure [17]. It decreased the tensile strength of the SPS edible films. Carrageenan is a sulfated polysaccharide that consists of $1,3 \mathrm{D}$ galactose-4 sulfated linked (Fig. 5). In aqueous solution, carrageenan has a random coil conformation, but upon heating and subsequent cooling, it forms thermoreversible gels in the presence of gel promoting cations. Carrageenan acts as a protector for starch granules [23]. The determination of the mechanical properties of the films can provide information on their applications. In some cases, food packaging should be deformable, while in other situations a high tensile strength of films is required to preserve food structure [24].

Elongation is the extendibility of film length from initial length to the point of break. This parameter helps to determine the flexibility and stretchability of the films [25]. The elongation of SPS edible films is shown in Fig. 6.

The elongation of SPS edible films ranged from 16.28-20.12\%. The elongation of modified SPS edible films was significantly higher than that of the native SPS films $(P<0.05)$. The longer durations of HMT had no significant effects on the elongation. Modification of SPS through HMT at high temperatures affects the polymer structure of starch and converts it into a regular flexible structure in the polymer matrix [13]. It increased the flexibility of SPS edible films.

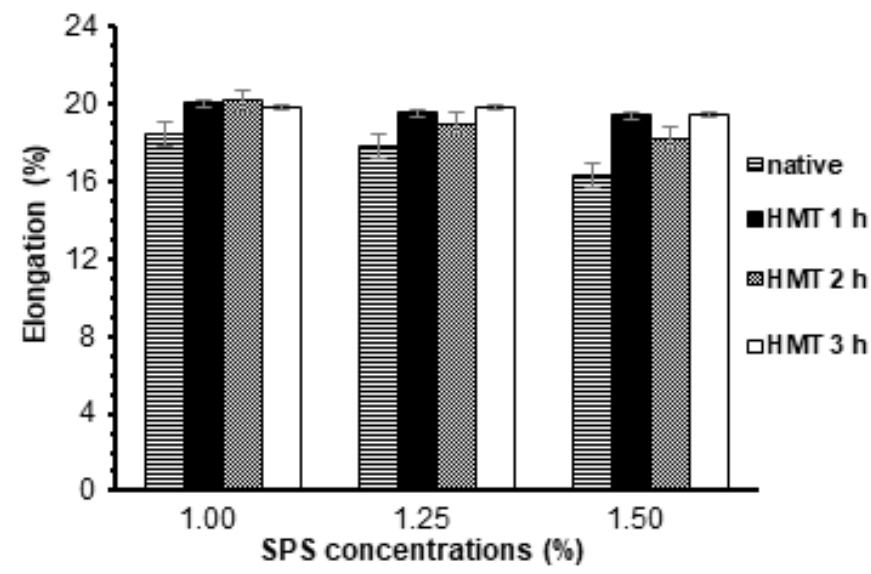

Fig 6. The elongation of SPS edible films with different durations of HMT and starch concentrations
The addition of $1.5 \%$ starch significantly decreased the elongation of the SPS edible films $(P<$ $0.05)$. The decrease and the increase of elongation were thought to be influenced by glycerol. Glycerol as a plasticizer has a small molecular weight that can be put into the intermolecular bond between amylose or the hydrogen bonds between starch and carrageenan. The glycerol molecule will impair the compactness of starch, decrease the intermolecular interaction and increase the mobility of polymers to improve elongation [25]. The addition of high starch concentration reduced the thermoplastic properties of film and the percentage of the elongation. A similar phenomenon has also been observed in corn starch-collagen composite films [19].

\section{Water Vapor Permeability (WVP)}

The ability of packaging materials to refrain or minimize moisture transfer between the food and the surrounding environment is a crucial property for effective food packaging. Minimum WVP of the edible films describes better barrier properties [25]. The WVP of SPS edible films is shown in Fig. 7.

Fig. 7 shows that the WVP of SPS edible films ranged from $0.554-0.707 \mathrm{~g} . \mathrm{mm} / \mathrm{m}^{2} \cdot \mathrm{kPa}$.day. The WVP of modified SPS edible films was significantly lower than

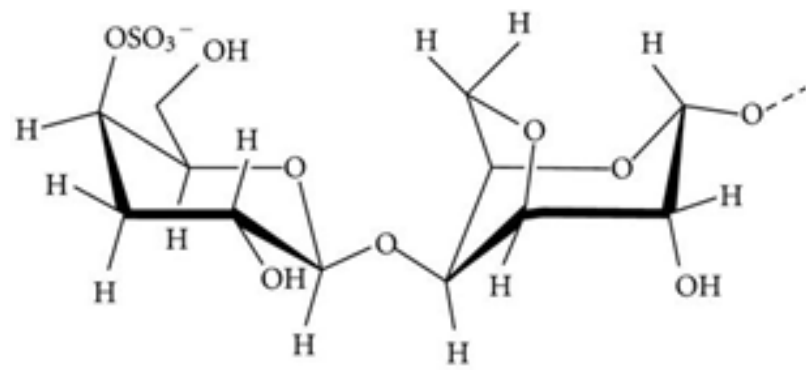

Fig 5. Structure of kappa-carrageenan

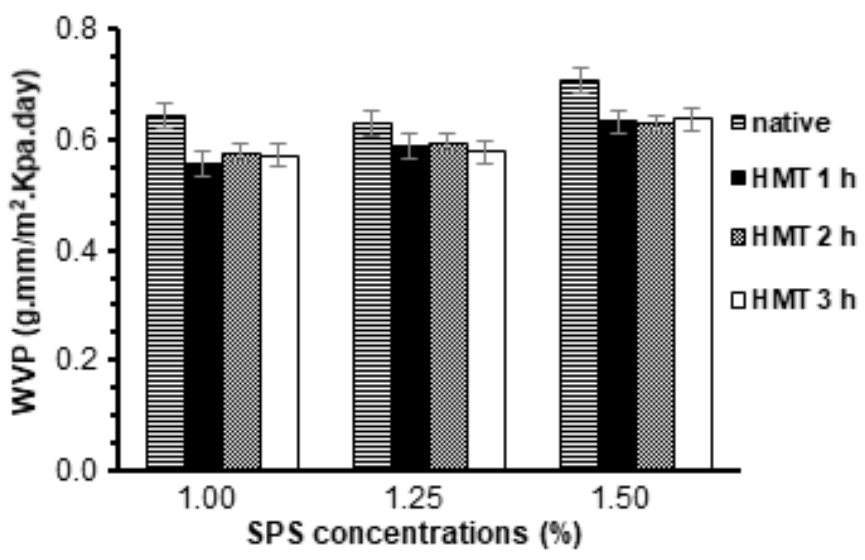

Fig 7. The WVP of SPS edible films with different durations of HMT and starch concentrations 
that of native SPS edible films $(P<0.05)$. The longer durations of HMT had no significant effect on the WVP. HMT caused the displacement of double helices between starch crystals and arranged the formation of a better packaged and ordered crystalline array than those of native starch [16]. HMT increased the starch crystallinity so that the film structure became more compact and minimized the moisture transfer. The WVP of SPS edible films in this study was similar to the WVP of the modified rice starch films $(0.648$ g. $\mathrm{mm} / \mathrm{m}^{2} . \mathrm{kPa}$.day) [15].

The WVP of the films increased significantly due to the addition $1.5 \%$ of sweet potato starch concentration $(P<0.05)$. The WVP values of starch films linearly enhance the increases in thickness [26]. The WVP value was influenced by water affinity which could be caused by hydrophilicity of starch. The high starch concentrations have a higher number of free hydroxyl groups which can form a hydrogen bond with water molecules [27]. It increased the water vapor permeability of the edible films.

\section{Solubility}

Film solubility in water is an essential property for selecting suitable food packaging plastics. The solubility of the films is advantageous in conditions when the films are consumed with a product (edible films). However, water insolubility may be required to enhance product integrity and water transfer resistance [7]. The solubility of SPS films is shown in Fig. 8.

Fig. 8 shows that the solubility of SPS edible films ranged from $25.37-46.84 \%$. Modified SPS by the HMT of $3 \mathrm{~h}$ resulted in the solubility of edible films that was lower than the native SPS films $(P<0.05)$. The reduced water solubility of the modified SPS edible films may have been attributed to the increasing interactions between amylose and amylopectin molecules and may strengthen intramolecular bonds promoted by the HMT of starch which reduced the capacity of the film to absorb water [22]. In addition, HMT produced a stronger crystalline structure to prevent granular swelling starch granules resulting in the decrease of the solubility of edible films [13].

The solubility of films decreased significantly as the starch concentration increased $(P<0.05)$. The thickness of films affected the solubility of films. The increase in starch concentration provided a thicker structure to the film matrix. Thus, it prevented water to enter the film matrix so that the film did not dissolve easily in water. Similar results were also reported on collagen-corn starch films [13].

\section{Morphology Analysis}

SEM micrographs of SPS edible films at a magnification of 1000x are presented in Fig. 9. The microstructure of SPS edible films was affected by the preparation of films and the HMT modification of starch. On the magnification of $1000 x$, it shows that the surfaces of the film of native SPS edible films had more cracks than those of modified SPS films. The films surfaces of modified SPS edible films appeared to be denser and compact than those of native SPS edible films.

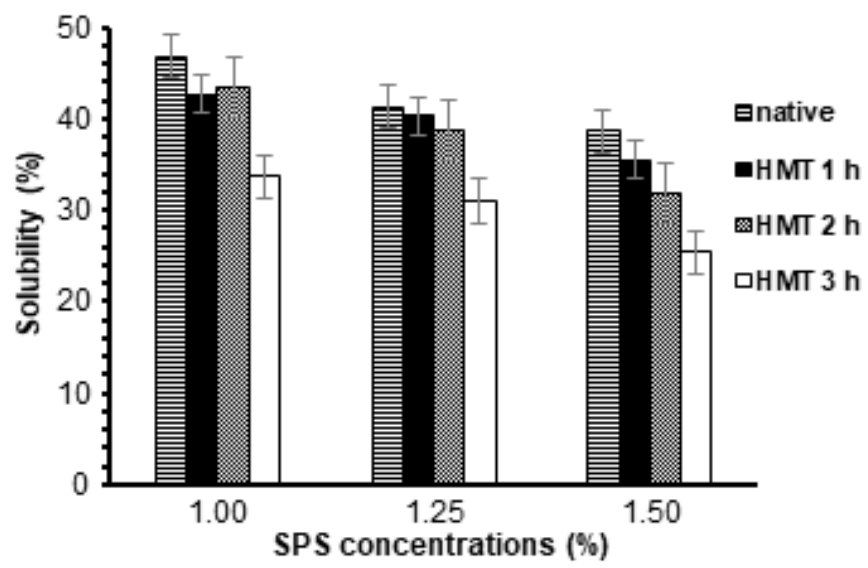

Fig 8. The solubility of SPS edible films with different durations of HMT and starch concentrations

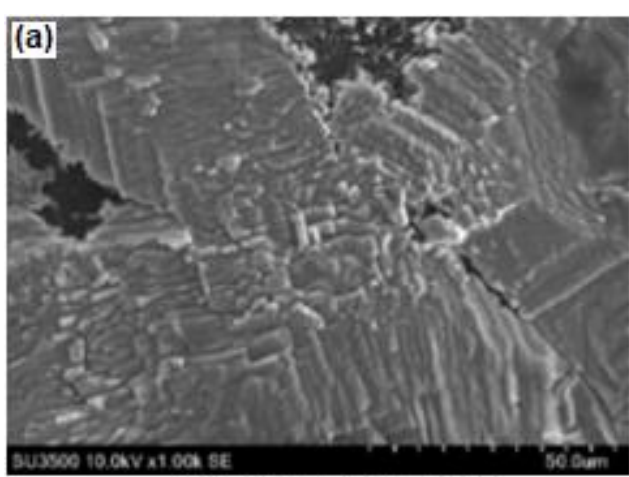

Magnification of $1000 x$

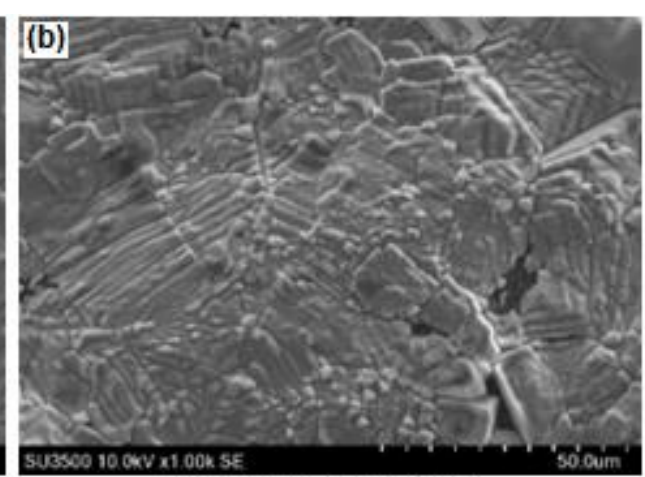

Magnification of $1000 \times$

Fig 9. SEM micrographs of films surfaces of native SPS films (a) and modified SPS films (b) 


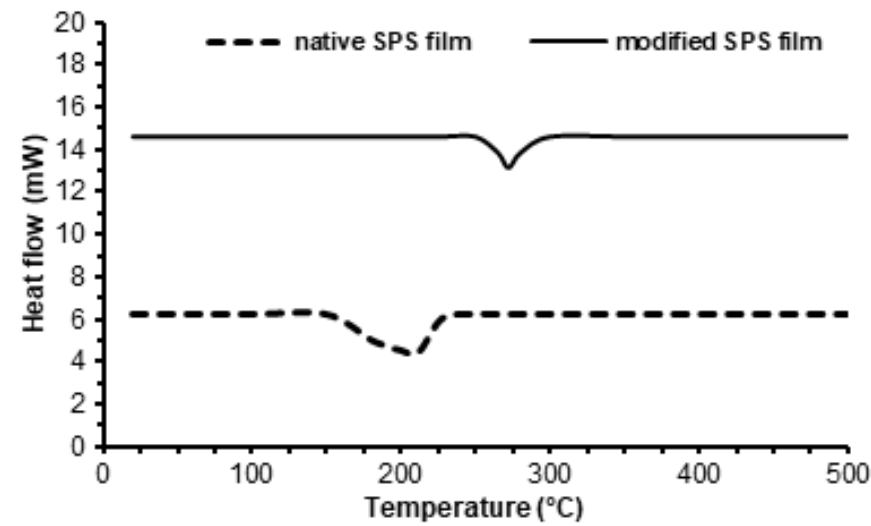

Fig 10. DSC curve of SPS edible films

HMT increases the interactions between amylose and amylopectin molecules and strengthens the intermolecular bonds of starch structure [12]. It made the matrix of the film more compact and dense. In addition, the rearrangement of molecular structure and disintegration of the central tissue during HMT caused the hollow structures on the surfaces of modified starch which formed the film matrix became to be more compact. The mechanical and barrier properties of SPS edible films were related to the microstructure of edible films. The compactness of the microstructure of modified SPS films showed the high tensile strength and low WVP of modified SPS edible films.

\section{Thermal Analysis}

Thermal transition temperatures were used for determining the sealing temperatures of polymers. Glass transition temperature $(\mathrm{Tg})$ is considered as one of the essential thermo-physical transitions for starch-based films. $\mathrm{Tg}$ is defined as the temperature in which the material undergoes a state transition from the glassy state to the viscous rubbery one [29]. The DSC curve of SPS edible films is shown in Fig. 10.

Fig. 10 shows that the $\mathrm{Tg}$ value of modified SPS films was higher than that of native SPS films. The $\mathrm{Tg}$ value of the native SPS film ranged from $179.9-227.6^{\circ} \mathrm{C}$, while the $\mathrm{Tg}$ of modified SPS film ranged from 265.3$278.8^{\circ} \mathrm{C}$ In modified SPS films, the amylose molecules were allowed to interact more freely with the amylopectin chains present in the branched crystalline regions. It consequently reduced the mobility of the amylopectin chains [12]. This increased glass transition temperatures. Glass transition temperatures were correlated with tensile strength films. In this study, the tensile strength of modified SPS films was higher than that of the native SPS films. HMT led a higher crystalline structure and increased the cohesive force in the starch

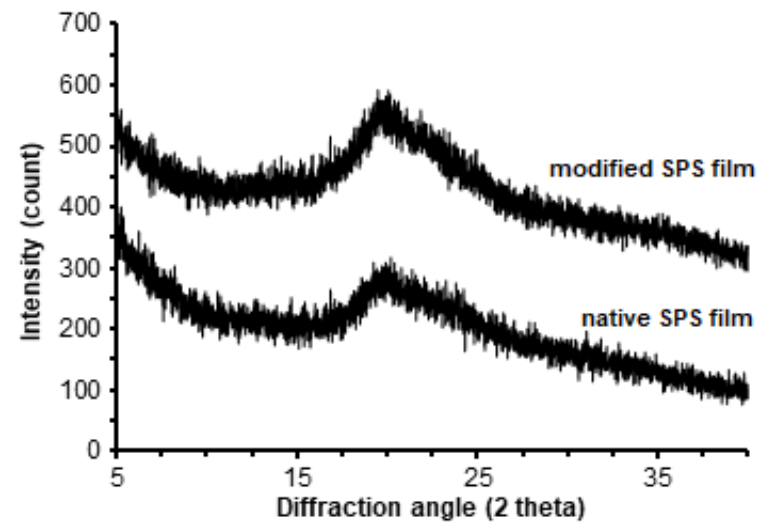

Fig 11. X-ray diffraction pattern of SPS edible films

granules so that the tensile strength increased [28].

\section{X-Ray Diffraction}

Fig. 11 shows that the X-ray diffraction pattern of modified SPS films looked similar to the respective native SPS films. The diffraction peaks of native and modified SPS films were observed with diffraction peaks at 2-theta of $20^{\circ}$. The crystallinity of the native and modified SPS films were 23.8 and $60.8 \%$, respectively. It indicated that the crystallinity of modified SPS film was higher than that of native SPS film.

The increase of crystallinity of the modified SPS films might be due to the further enhanced associations between starch chains and the rearrangement of the disrupted double helices within the crystalline regions that led to an increase in crystal perfection or the formation of new crystallite [16]. The high crystallinity of the modified SPS film enhanced the compactness of the film structure so that the tensile strength increased while the WVP decreased.

\section{CONCLUSION}

Modified SPS through HMT increased the thickness, the tensile strength, and the elongation of SPS films. On the other hand, it decreased the solubility and the WVP of SPS films. The longer durations of HMT had no effects on the characteristics of edible films. The increase of SPS concentrations $(1.5 \%)$ enhanced the moisture content, the thickness, and the WVP but decreased the tensile strength, the elongation, and the solubility of edible films. The modified SPS film had a compact and dense film surfaces. The crystallinity and the thermal properties of the modified SPS film showed more increased than that of the native SPS film. 


\section{ACKNOWLEDGEMENT}

The authors thank the Centre of Appropriate Technology Development to support the materials and the instruments for this research.

\section{REFERENCES}

[1] Laohakunjit, N., and Noomhorm, A., 2004, Effect of plasticizers on mechanical and barrier properties of rice starch film, Starch - Stärke, 56 (8), 348-356.

[2] Mahmudatussa'adah, A., 2014, Komposisi kimia ubi jalar (Ipomoea batatas L.) Cilembu pada berbagai waktu simpan sebagai bahan baku gula cair, Pangan, 23 (1), 53-64.

[3] Jiménez, A., Fabra, M.J., Talens, P., and Chiralt, A., 2012, Edible and biodegradable starch films: A review, Food Bioprocess Technol., 5 (6), 20582076.

[4] Hoover, R., and Manuel, H., 1996, Effect of heatmoisture treatment on the structure and physicochemical properties of normal maize, waxy maize, dull waxy maize and amylomaize $V$ starches, J. Cereal Sci., 23 (2), 153-162.

[5] Abdorreza, M.N., Cheng, L.H., and Karim, A.A., 2011, Effects of plasticizers on thermal properties and heat sealability of sago starch films, Food Hydrocolloids, 25 (1), 56-60.

[6] Maran, J.P., Sivakumar, V., Sridhar, R., and Thirugnanasambandham, K., 2013, Development of model for barrier and optical properties of tapioca starch based edible films, Carbohydr. Polym., 92 (2), 1335-1347.

[7] Sanyang, M.L., Sapuan, S.M., Jawaid, M., Ishak, M.R., and Sahari, J., 2016, Effect of plasticizer type and concentration on physical properties of biodegradable films based on sugar palm (Arenga pinnata) starch for food packaging, J. Food Sci.Technol., 53 (1), 326-336.

[8] Li, J., Ye, F., Liu, J., and Zhao, G., 2015, Effects of octenylsuccination on physical, mechanical and moisture-proof properties of stretchable sweet potato starch film, Food Hydrocolloids, 46, 226-232.

[9] Sun, Q., Wang, T., Xiong, L., and Zhao, Y., 2013, The effect of heat moisture treatment on physicochemical properties of early indica rice, Food Chem., 141 (2), 853-857.

[10] Pranoto, Y., Rahmayuni, Haryadi, and Rakshit, S.K., 2014, Physicochemical properties of heat moisture treated sweet potato starches of selected Indonesian varieties, Int. Food Res. J., 21 (5), 2031-2038.

[11] Rafiq, S.I., Singh, S., and Saxena, D.C., 2016, Effect of heat-moisture and acid treatment on physicochemical, pasting, thermal and morphological properties of Horse Chestnut (Aesculus indica) starch, Food Hydrocolloids, 57, 103-113.

[12] Tan, X., Li, X., Chen, L., Xie, F., Li, L., and Huang, J., 2017, Effect of heat-moisture treatment on multi-scale structures and physicochemical properties of breadfruit starch, Carbohydr. Polym., 161, 286-294.

[13] Zavareze, E.R., Pinto, V.Z., Klein, B., El Halal, S.L.M., Elias, M.C., Prentice-Hernández, C., and Dias, A.R.G., 2012, Development of oxidized and heat-moisture treated potato starch film, Food Chem., 132(1), 344-350.

[14] Singh, G.D., Bawa, A.S., Riar, C.S., and Saxena, D.C., 2009, Influence of heat-moisture treatment and acid modifications on physicochemical, rheological, thermal and morphological characteristics of Indian water chestnut (Trapa natans) starch and its application in biodegradable films, Starch - Stärke, 61 (9), 503-513.

[15] Majzoobi, M., Pesaran, Y., Mesbahi, G., Golmakani, M.T., and Farahnaky, A., 2015, Physical properties of biodegradable films from heat-moisture treated rice flour and rice starch, Starch - Stärke, 67 (11-12), 1053-1060.

[16] Klein, B., Pinto, V.Z., Vanier, N.L, Zavareze, E.R., Colussi, R., do Evangelho, J.A., Gutkoski, L.C., and Dias, A.R.G., 2013, Effect of single and dual heat-moisture treatments on properties of rice, cassava, and pinhao starches, Carbohydr. Polym., 98 (2), 1578-1584.

[17] Thakur, R., Saberi, B., Pristijono, P., Golding, J., Stathopoulos, C., Scarlett, C., Bowyer, M., and Vuong, Q., 2016, Characterization of rice starch-ıcarrageenan biodegradable edible film. Effect of stearic acid on the film properties, Int. J. Biol. Macromol., 93 (Pt A), 952-960.

[18] Rhim, J.W., and Wang, L.F., 2013, Mechanical and water barrier properties of agar $/ \mathrm{k}$ carrageenan/konjac glucomannan ternary blend biohydrogel films, Carbohydr. Polym., 96 (1), 7181.

[19] Wang, K., Wang, W., Ye, R., Liu, A., Xiao, J., Liu, Y., and Zhao, Y., 2017, Mechanical properties and solubility in water of corn starch-collagen composite films: Effect of starch type and concentrations, Food Chem., 216, 209-216.

[20] Velickova, E., Winkelhausen, E., Kuzmanova, S., and Alves, V.D., 2013, Impact of chitosanbeeswax edible coatings on the quality of fresh strawberries (Fragaria ananassa cv Camarosa) under commercial storage conditions, LWT Food Sci. Technol., 52 (2), 80-92.

[21] Gutiérrez, T.J., Tapia, M.S., Pérez, E., and Famá, L., 2015, Structural and mechanical properties of 
edible films made from native and modified cushcush yam and cassava starch, Food Hydrocolloids, 45, 211-217.

[22] Huang, T.T., Zhou, D.N., Jin, Z.Y., Xu, X.M., and Chen, H.Q., 2016, Effect of repeated heat-moisture treatments on digestibility, physicochemical and structural properties of sweet potato starch, Food Hydrocolloids, 54 (Part A), 202-210.

[23] Huc, D., Matignon, A., Barey, P., Desprairies, M., Mauduit, S., Sieffermann, J.M., and Michon, C., 2014, Interactions between modified starch and carrageenan during pasting, Food Hydrocolloids, 36, 355-361.

[24] Supeni, G., Cahyaningtyas, A.A., and Fitrina, A., 2015, Karakterisasi sifat fisik dan mekanik penambahan kitosan pada edible film karagenan dan tapioka termodifikasi, Jurnal Kimia dan Kemasan, 37 (2), 103-110.

[25] Sanyang, M.L., Sapuan, S.M., Jawaid, M., Ishak,
M.R., and Sahari, J., 2015, Effect of plasticizer type and concentration on tensile, thermal and barrier properties of biodegradable films based on sugar palm (Arenga pinnata) starch, Polymers, 7 (6), 1106-1124.

[26] Khazaei, N., Esmaiili, M., Djomeh, Z.E., Ghasemlou, M., and Jouki, M., 2014, Characterization of new biodegradable edible film made from basil seed (Ocimum basilicum L.) gum, Carbohydr. Polym., 102, 199-206.

[27] Warkoyo, Rahardjo, B., Marseno, D.W., and Karyadi, J.N.W., 2014, Sifat fisik, mekanik, dan barrier edible film berbasis pati umbi kimpul (Xanthosoma sagittifolium) yang diinkorporasi dengan kalium sorbat, Agritech, 34 (1), 72-81.

[28] Zhang, P., Zhao, Y., and Shi, Q., 2016, Characterization of a novel edible film based on gum ghatti: Effect of plasticizer type and concentration, Carbohydr. Polym., 153, 345-355. 